Monika OŻÓG

(Opole, UO)

\title{
PODRÓŻE MNICHÓW I DUCHOWNYCH W ŚWIETLE PISM ŚWIĘTEGO HIERONIMA
}

Hieronim ze Strydonu ${ }^{1}$ - autor przekładu na łacinę Pisma Świętego oraz Onomastikonu Euzebiusza z Cezarei, przyczynił się także w bardzo dużej mierze do popularyzacji i rozwoju ruchu turystyczno-pielgrzymkowego na przełomie IV i V wieku. Dla osób wybierających się w tym okresie w podróż do Ziemi Świętej, podstawowymi ,przewodnikami” były te, które wyszły spod pióra Hieronima. Nowy przekład Pisma Świętego intrygował nowościami ${ }^{2}$ i dawał nowe możliwości jego zrozumienia, zaś Onomastikon ${ }^{3}$ był podstawowym tekstem, w którym omówione i wyjaśnione zostały nazwy biblijnych miejscowości ${ }^{4}$.

Wśród dorobku pisarskiego Hieronima możemy odnaleźć wiele wzmianek dotyczących podróży ówczesnych duchownych ${ }^{5}$ i mnichów. Niniejszy tekst opiera się zasadniczo na jego Listach, które są olbrzymim zasobem informacji

\footnotetext{
${ }^{1}$ Hieronim, późniejszy doktor Kościoła, urodził się w 331 bądź 347 r. w Strydonie, niedaleko granicy Dalmacji i Panonii, a zmarł w Betlejem, w 419 lub 420 r., por. M. Ożóg, Wprowadzenie, w: Hieronim ze Strydonu, Listy, t. 1 (1-50), ŹMT 54 [wydanie łacińsko-polskie, tekst łaciński opracował H. Pietras, tłum. J. Czuj, oprac. M. Ożóg, wyd. WAM], Kraków 2010, s. V-XIV.

${ }^{2}$ Hieronim przełożył Biblię Starego Testamentu z języka hebrajskiego, a nie z greckiej Septuaginty, na której opierał się poprzedni przekład (vetus latina). Oprócz wspomnianej Septuaginty, istniały inne greckie przekłady Biblii, mianowicie dosłowna wersja Akwili, swobodne thumaczenie Symmacha, a także poprawione wydanie Septuaginty sporządzone przez Teodocjona. Żaden z tych tekstów nie był jednak wystarczająco zgodny z oryginałem hebrajskim, by - zdaniem Hieronima mógł stanowić podstawę tłumaczenia.

${ }^{3}$ Por. Onomasticon, PL 23, 903-976; lub ed. E. Klosterman, GCS 11/1, Leipzig 1904; R. Jiménez Zamudio, Algunas observaciones sobre la estructura del „Onomasticon” de Eusebio y la versión latina de Jerónimo, „Fortunatae” 17 (2006) 65-78.

${ }^{4}$ Onomastikon czyli Liber locorum, jak został nazwany przez autora przekładu, zasadniczo obejmował tekst Euzebiusza z Cezarei, który Hieronim wzbogacił o pewne fragmenty, przy jednoczesnym pominięciu niektórych części oryginalnego tekstu. Hieronim uważał, że kopiści Onomastikonu Euzebiusza dodawali w nim wiele od siebie i dlatego skorygował pewne informacje, wykorzystując w tym też celu własne wędrówki po Ziemi Świętej, por. J. Wilkinson, L'apport de Saint Jérome a la Topographie, RB 81 (1974) 246.

${ }^{5} \mathrm{Na}$ przełomie IV/V wieku pojęcie duchowni, czyli clerus, obejmowało siedem stopni: ostiariusz, lektor, akolita, egzorcysta, subdiakon diakon, prezbiter i biskup nad nimi. List Ps-Hieroni-
} 
m.in. na temat podróżowania w okresie wczesnego chrześcijaństwa, w tym o wyprawach do Ziemi Świętej. Korespondencja, która wchodzi w skład tego epistolarium, podaje nam bardzo wiele danych na temat motywów odbycia podroży, którymi kierowali się ówcześni pielgrzymi. Dużo w niej opisywania tamtejszych tras turystyczno-handlowych, a także obaw i radości z nimi związanych.

W zbiorze listów Hieronima - choć nie tylko on jest ich autorem - odnajdujemy kilka pism, dotyczących wyłącznie poruszanego zagadnienia. Jeden z nich, napisany przez dwie wysoko urodzone matrony rzymskie - Paulę oraz Eustochium (matkę i córkę) do przyjaciółki Marceli około 392/3 r., zachęca do odwiedzenia Jerozolimy ${ }^{6}$. Drugi zaś autorstwa samego Hieronima, będący panegirykiem ku czci zmarłej Pauli, został zaadresowany do jej córki Eustochium $^{7}$. Tekst ten powstał wiosną $404 \mathrm{r}$. i oprócz wielkiej pochwały życia bardzo pobożnej kobiety, zawiera dokładny opis jej podróży, w której zresztą autor był przewodnikiem ${ }^{8}$. W innych listach zbioru, choć nie stanowią one rzeczywistych relacji z podróży, możemy również uzyskać wiele wzmianek na ten temat ${ }^{9}$.

Podróż Hieronima (wraz z towarzyszącymi mu osobami) do Jerozolimy, pod koniec IV wieku, była jedną z najbardziej odkrywczych wypraw tamtego czasu. Hieronim pisał, że każdy chrześcijański uczony powinien odwiedzić Ziemię Święta, identycznie, jak myśliciel grecki - Ateny, zaś łaciński - Rzym $^{10}$. Już wtedy, dzięki popularyzacji odwiedzin Ziemi Świętej, przez odpowiednio nagłośnioną budowę bazylik przez Konstantyna oraz rodzącą się legendę o odkryciu drzewa Krzyża Świętego, rozpowszechnianą przez Helenę $e^{11}$ - matkę Konstantyna, starano się szukać i identyfikować miejsca znane z Pisma Świętego. Trzeba przyznać, że efekty przedstawiały się imponująco. Chęć podróżowania i zwiedzania łączyła się z odwiedzaniem grobów wczesnych męczenników ${ }^{12}$, a także $\mathrm{z}$ coraz większym zainteresowaniem cudowno-

ma (PL 30, 148) wymienia także grabarza. Mnich zaliczał się do duchowieństwa, jeśli miał jakieś święcenia.

${ }^{6}$ Por. Hieronymus, Epistula 46, 1, ŹMT 54, Kraków 2010, 186.

${ }^{7}$ Por. A. Cain, Jerome's „Epitaphium Paulae”. Hagiography, pilgrimage, and the cult of Saint Paula, JECS 18 (2010) 105-139.

${ }^{8}$ Por. Hieronymus, Epistula 108, ŹMT 61, Kraków 2011, 159-188.

${ }^{9}$ Tak np. w liście 58., skierowanym do Paulina, Hieronim doradza adresatowi podróż do Palestyny, przy okazji nadmieniając mu o przeszkodach, jakie musiałby znosić w tak wielkim mieście jak Jerozolima. W liście zaś 78. do Fabioli - opisuje i objaśnia drogę wyjścia Izraelitów z Egiptu, a w liście 129. do Dardana możemy odnaleźć opis granic Ziemi Obiecanej.

${ }^{10}$ Por. Hieronymus, In Paralipomenon Praef. 70, PL 29, 401A.

${ }^{11}$ Por. Socrates Scholasticus, HE I 17, SCh 477, 174-180, thum. S. Kazikowski : Sokrates Scholastyk, Historia Kościoła, Warszawa 1986, 109-112; A. Frolow, La relique de la Vraie Croix, Paris 1981.

${ }^{12}$ Por. R. Wiśniewski, Narodziny kultu relikwii i jego najwcześniejsze świadectwa, w: Poczatki kultu relikwii na Zachodzie, red. R. Wiśniewski, Warszawa 2011, 11-47. 
ścią oraz samymi cudami. Nie bez znaczenia były też piękne krajobrazy, które podróżnicy $\mathrm{z}$ wielką ochotą podziwiali ${ }^{13}$.

Hieronim do grudnia 384 r. miał bardzo silną pozycję w Kościele rzymskim. Z chwilą śmierci jego protektora, papieża Damazego, sytuacja uległa niekorzystnej zmianie. Nie bez podstaw stał się on ofiarą pomówień o niestosowne kontakty z kobietami, a w szczególności, powszechnie występujące wiadomości na temat jego relacji i spotkań z Paulą. Planowana wspólnie podróż do Ziemi Świętej była dodatkowym źródłem skandalu. Do tych pogłosek doszła jeszcze krytyka wielu osób, zarzuty fascynacji Orygenesem, zbytniej propagandy ascezy, radykalnej zmiany trybu życia oraz spowodowania śmierci umartwiającej się aż po tragiczny finał Blezylli. Była ona córką Pauli i niektórzy sądzili, że za tę śmierć odpowiedzialny był Hieronim, poprzez nakłanianie dziewczyny do zbyt rygorystycznych postów. Być może, został on uniewinniony od stawianego mu zarzutu, z pewnością nie miała do niego pretensji Paula, matka zmarłej, natomiast na pewno dano mu do zrozumienia stosowność opuszczenia Rzymu, co prawdopodobnie miało jaką̧́ formę urzędowo obowiązującą ${ }^{14}$. Biorąc pod uwagę zaistniałe okoliczności i złośliwe komentarze na temat wspólnej wyprawy do Jerozolimy, Hieronim i Paula postanowili część trasy odbyć osobno.

1. O podróży lądowej. Droga, jaką zamierzali przebyć, nie należała do tras łatwych. Podróżni mieli wybór pomiędzy najszybszą i najwygodniejszą drogą morską, oraz szlakiem lądowym. Droga lądowa wiodła raczej uczęszczanymi traktami, które w dodatku były używane przez pocztę państwową ${ }^{15}$. Podróżni, pochodzący ze znakomitych rodów, zajmujący wysokie stanowiska bądź też posiadający odpowiednie znajomości, mogli liczyć na usługi poczty publicznej i nią podróżować. W ten sposób przemieszczała się np. Melania Młodsza, której wysoko postawiony wuj załatwił audiencję u cesarza Teodozjusza II i jego żony Eudoksji, dzięki czemu uzyskała pozwolenie na odbycie podróży na koszt państwa ${ }^{16}$.

By podróżować poczta, czyli na koszt państwa (cursus publicus), należało mieć specjalne pozwolenie (diploma). Zezwoleniem częściowym było evectio, które Hieronim określa terminem synthema (co po grecku znaczy pieczęć, dokument). W liście do Juliana Hieronim, używając właśnie tego terminu pisał: „Już było zezwolenie na jazdę, konia osiodłano”"17. Ważność owych pasz-

${ }^{13}$ Por. B. Leyerle, Landscape as cartography in early Christian pilgrimage narratives, ,Journal of the American Academy of Religion" 64 (1996) 130-132.

14 Por. J.N.D. Kelly, Jerome. His life, writings, and controversies, London 1975, 134 (thum. R. Wiśniewski: Hieronim. Życie, pisma, spory, Warszawa 2003, 136-137).

${ }^{15}$ Por. np. F. Jakubowski, Cursus publicus - poczta rzymska, „Meander” 5 (1950) 75-81.

${ }^{16}$ Por. D. Gorce, Les voyages l'hospitalité et le port des letters. Dans le monde chrétien des IV et Viécles, Paris 1925, 49.

${ }^{17}$ Hieronymus, Epistula 118, 1, ŹMT 63, Kraków 2011, 29. 
portów była surowo kontrolowana, a nielegalna sprzedaż samych pozwoleń groziła śmiercią. Istniały także pełnomocnictwa pełne (trattoria), które oprócz zgody na transport obejmowały wyżywienie. Niestety takiego paszportu nie posiadała wspomniana Melania, o czym świadczy jedna z jej wypraw, podczas której funkcjonariusz posterunku w Trypolisie nie wyraził zgody na to, aby wydać jej niezbędne zwierzęta. Przyczyną takiego zachowania był fakt, że zezwolenie, które posiadała kobieta, dotyczyło tylko jej osoby, a nie całej gromady towarzyszy. Łapówka - trzy sztuki złota - wręczona przez kobietę, rozwiązała ten problem ${ }^{18}$.

Naturalnie, od początku pojawiały się pewne nadużycia przy tego rodzaju transporcie. Umiaru w korzystaniu $\mathrm{z}$ wozu pocztowego nie miał podobno biskup Grzegorz z Nyssy, który nie dość, że nim podróżował, to w dodatku w nim zamieszkał i zamienił go wręcz w podróżną kaplicę. Aby ukrócić państwowe nadużycia, wiążące się $\mathrm{m}$. in. $\mathrm{z}$ kwestią używania powozów pocztowych, Julian Apostata wydał w tym celu odpowiedni dekret (362 rok) ${ }^{19}$.

Tak jak zostało wspomniane, podstawowym środkiem komunikacji był wówczas wóz, zaprzężony w rozmaite zwierzęta. Jan Chryzostom opuszczał Konstantynopol w lektyce niesionej przez dwa muły - jeden z przodu a drugi z tyłu ${ }^{20}$, święty Marcin z Tour podróżował po Galii również na tym zwierzę$\mathrm{ciu}^{21}$. Hieronim podkreślał wielkie poświęcenie Pauli, która, mimo że był to środek zimy, jechała na grzbiecie osiołka ${ }^{22}$. Najbardziej luksusowym zwierzęciem w podróży był koń, z którego jednak korzystali najbogatsi. W trudniejszym terenie, jak na przykład na pustyni, jedynym środkiem transportu ludzi i ładunków były wielbłądy (o tym sposobie przemieszczania się pisała Egeria $^{23}$ ), zaś na wielu odcinkach musiały podróżnym wystarczyć własne nogi.

Kto nie miał uprawnień i znajomości, by odbyć podróż na koszt państwa, był zmuszony sam sfinansować sobie transport i wynająć wóz u jednego z licznych przedsiębiorców przewozowych. Na uczęszczanych trasach istniały tzw. mansiones, gdzie podróżni mogli się zatrzymać. Z kolei mutationes, oferowa-

${ }^{18}$ Por. Gorce, Les voyages, s. 226.

19 Por. CTh VIII 1, 6, ed. Th. Mommsen - P.M. Meyer, Berlin 1962: „Imp. Iulianus a. ad Auxonium correctorem Tusciae. Numerarii, qui publicas rationes civitatum versutis fraudibus lacerare didicerunt, subiaceant tortori nomine artis ac fraudis. Verum cum quinquennio administraverint chartas publicas, unum integrum annum vacent, ut ad incusantium iurgia facilis adpetitu sit vita privata. Septimo porro anno, cum eosdem bene creditum munus administrasse claruerit, ex perfectissimis dimittantur. Hic abolebit honor dignitatis additae veterem vilitatem. Dat. XVI kal. feb. Constantinopoli Mamertino et Nevitta conss (362 ian. 17)”.

${ }^{20}$ Por. Gorce, Les voyages, s. 71.

${ }^{21}$ Por. tamże, s. 70.

22 Por. Hieronymus, Epistula 108, 7, ŹMT 61, 164.

${ }^{23}$ Por. Egeria, Peregrinatio ad loca sancta 6, 2, SCh 296, 150, tłum. P. Iwaszkiewicz: Pielgrzymka do miejsc świętych, w: Do Ziemi Świętej. Najstarsze opisy pielgrzymek do Ziemi Świętej IV-VIII w., OŻ 13, wstęp i oprac. P. Iwaszkiewicz, przedm. M. Starowieyski, Kraków 1996, 148. 
ły wymianę zmęczonych drogą zwierząt na świeże. Większość znanych nam podróżnych z tego czasu, była zamożna, bądź przemierzała drogę z osobami majętnymi. Wyprawy należały do kosztownych. Pewną skalę porównawczą daje nam ustawa Dioklecjana o cenach maksymalnych - Edictum Diocletiani de pretiis rerum venalium z 301 roku. Według niego opłata za przewóz jednego człowieka wozem podróżnym, za jedną milę, wynosiła 2 denary, zaś wynajęcie całego wozu podróżnego wiązało się z wydatkiem do 20 denarów na milę ${ }^{24}$. Porównując te kwoty do ówczesnych płac, zarobek człowieka pracującego na roli oscylował w wysokości 25 denarów dziennie ${ }^{25}$.

Należy też zwrócić uwagę na różnego typu przeszkody, na które narażone były podróżujące osoby: począwszy od niezbyt dobrego stanu dróg i nieprawidłowo wyznaczonych tras (w szczególności na pustyni), zmiany klimatu, a skończywszy na chorobach (częsta była febra czyli malaria), z którymi podróżni musieli się zmagać. W liście do Rufina, Hieronim pisze:

„Wreszcie gdy błądząc w niebezpiecznej podróży przemierzyłem Trację, Pont, Bitynię oraz drogi Galacji i Kapadocji i kiedy dała mi się we znaki Cylicja ze swoimi upałami, ujrzałem Syrię, która ukazała mi się jak rozbitkowi port wzbudzający największą ufność. Tam, doświadczywszy wszelkich chorób, jedno z dwojga oczu utraciłem, to znaczy Innocentego ${ }^{26}$, tego bowiem serdecznego przyjaciela zabrała nagle febra"'27.

Zapewne niejednemu podróżnemu przytrafiła się przygoda, którą opisuje św. Hieronim w Żywocie mnicha Malchusa wziętego do niewolii ${ }^{28}$. Otóż Malchus podróżował z Beroi (Syria) do Edessy (Mezopotamia) wraz z podobnymi wędrowcami. Cała karawana (licząca około 70 osób) została napadnięta i uwięziona przez Saracenów, zaś samego Malchusa uprowadzono do niewoli. Do posiadłości nowego pana wieziono go na wielbłądzie, jego pożywieniem było półsurowe mięso i wielbłądzie mleko. Dopiero po długim czasie udało mu się uciec ${ }^{29}$. Oczywiście, pustynni koczownicy nie ograniczali się tylko do pogranicznych rozbojów, potrafili również atakować większe osiedla i skupiska monastyczne, takie jak Nitria czy Sketis ${ }^{30}$. Hieronim także w Listach podkreśla, że w czasach jemu współczesnych, Pax Romana należał do prze-

${ }^{24}$ Por. Edictum Diocletiani de pretiis rerum venalium (Edykt Dioklecjana o cenach towarów wystawionych na sprzedaż), tłum., wstęp i oprac. A. i P. Barańscy - P. Janiszewski, Poznań 2007, 71. Wozy pocztowe pokonywały w ciagu dnia 20 mil.

${ }^{25}$ Choć ustawa była w swym zamierzeniu od samego początku nierealna i została uchylona w cztery lata po jej uchwaleniu, to jednak daje pewne odzwierciedlenie ówczesnych cen, por. tamże, s. 50.

${ }^{26}$ Chodzi o Innocentego - przyjaciela Hieronima, adresata pierwszego listu.

${ }^{27}$ Hieronymus, Epistula 3, 3, ŹMT 54, 8.

${ }^{28}$ Por. Hieronymus, Vita Malchi monachi captivi 4, PL 23, 55, tłum. B. Degórski, ŹM 10, 181-182.

${ }^{29}$ Niniejsze opowiadanie jest być może hagiograficzną fikcją.

${ }^{30}$ Por. Hieronymus, Chronicon (a. 375), ed. R. Helm, GCS 47, Berlin 1956, 248; Ch.A. Frazee, 
szłości, zaś barbarzyńcy, którzy z południa i północy atakowali Imperium, wywoływali wiele lęków wśród podróżników.

2. Podróż Hieronima. Hieronim zdecydował się na podróż morską do Ziemi Świętej. W sierpniu 385 r., wraz ze swoim bratem Paulinianem, przyjacielem Wincentym oraz kilkoma mnichami, wsiadł na statek i już na stałe opuścił Rzym (Babilon) ${ }^{31}$. Z Apologii, którą wystosował do Rufina, dowiadujemy się, że:

,[...] gdy wiały od północy letnie wiatry, wsiadłem bezpiecznie na statek w rzymskim porcie [Portus] razem ze świętym kapłanem Wincentym i z młodszym bratem oraz innymi mnichami, którzy teraz przebywają w Jerozolimie, a towarzyszyła mi wielka liczba wiernych. Przypłynąłem do Regium [obecnie: Reggio Calabria], a u wybrzeży Sycylii [Cieśnina Messyńska] na krótki czas zatrzymałem się. Tam usłyszałem stare legendy oraz o niebezpiecznej podróży sprytnego Ulisa, o pieśniach syren i o żarłoczności nienasyconej Charybdy"32.

Okoliczni mieszkańcy, przyjmując go bardzo serdecznie, poradzili mu, w jaki sposób ma odbyć kolejny etap podroży i przestrzegali:

„Abym nie płynął ku kolumnom Proteusza na Faros [Aleksandria], ale do portu Jonium [Jaffa], tamten bowiem kurs to droga uciekinierów i rozbitków, ten zaś ludzi bezpiecznych, spokojnych"33.

Hieronim licząc na gościnę u biskupa Salaminy Epifaniusza, skorzystał z innej możliwości: ominął niebezpieczny przylądek Malea oraz Cyklady i w ten sposób dostał się na Cypr, gdzie w Salaminie spotkał się ze wspomnianym biskupem. Następnie udał się do Seleucji ${ }^{34}$ - portu na wybrzeżu Syrii - i stąd wyruszył do Antiochii. Tu zatrzymał się w domu Ewagriusza, skąd - jak pisze - ,w środku zimy i w najostrzejszym mrozie wkroczyłem do Jerozolimy" 35 .

3. O podróży morskiej. Hieronim wybrał więc rejs statkiem i stąd też w jego pismach możemy odnaleźć wiele istotnych wiadomości o ówczesnym

Late Roman and Byzantine legislation on the monastic life from the fourth to the eighth Centuries, ChH 51 (1982) 264.

${ }^{31}$ Babylon oznacza confusio - zamieszanie, zamęt. Hieronim porównuje tu Rzym do Babilonu jako do miasta grzesznego, por. Hieronymus, Epistula 7, 3, ŹMT 54, 18. Podstawowe informacje na temat szlaków wiodących do Rzymu, por. B. Pawłowska, Urbs Sacra, Kraków 2007, 93-101.

${ }^{32}$ Hieronymus, Apologia adversus Rufinum III 22, ed. P. Lardet, SCh 303, 272, thum. S. Ryznar, PSP 61, Warszawa 1989, 119. Tłumaczenie zostało poprawione przez autorkę artykułu.

${ }^{33}$ Tamże. Większe poczucie bezpieczeństwa opierało się zapewne na założeniu, że podróż wzdłuż wybrzeża jest pewniejsza od przepływania w poprzek morza,

${ }^{34}$ Został on założony przez Seleukosa I Nikanora około 300 r. prz. Chrystusem.

${ }^{35}$ Hieronymus, Apologia adversus Rufinum III 22, SCh 303, 272, PSP 61, 120. 
żeglowaniu ${ }^{36}$ i samych podróżach morskich. Należy pamiętać, że w tamtym czasie porty otwarte były ogólnie od wczesnej wiosny do końca październi$\mathrm{ka}^{37}$. Ostatecznie 12 listopada zamykano na łańcuchy wejście do portów morskich (mare clausum) ${ }^{38}$. W jednym z listów Hieronim pisze, że ,gdy upłynęła zima i morze nadawało się do żeglugi” 39 można było podróżować droga morską. Dowiadujemy się również, że w nocy żeglowanie ułatwiały gwiazdy, a pomocą w nawigacji była mapa, o której pisał: „I jak ci, którzy malują na małej tabliczce położenie krajów"40.

W związku z tym, że w tym czasie nie było jeszcze statków wyłącznie pasażerskich, podróżowano statkami handlowymi. Hieronim wiele razy wymienia różne elementy składowe jednostek pływających, jak np. kadłub ${ }^{41}$, rumpel i wiosło sterowe ${ }^{42}$, żagle $^{43}$, czy wiosła ${ }^{44}$. Używa też wielu terminów określających typy statków: cumba ${ }^{45}$, navicula ${ }^{46}$ czy navis oneraria ${ }^{47}$.

W zbiorze Listów odnajdujemy też notę, sporządzoną przez biskupa Teofila, do biskupów egipskich, w której opisał sposób żeglowania na pełnym morzu:

„Sternicy wielkich okrętów, widząc nadchodzący z głębi morza potężny wir, kierują się na spienione fale, jakby łowcy na dziką bestię, i wstrzymują je nastawionym dziobem okrętu, pomagając sobie obrotem steru i przyciagając lub popuszczając liny, stosownie do potrzeby i kierunku wiatru; a gdy fala opadnie, opuszczają z obydwóch boków okrętu nadwyrężone wiązania sterowe, by wypocząwszy nieco, przygotowały się na następny wir; a gdy znów ten nadejdzie, ściaggają głowice sterów i rozszerzają wiosła, aby przez rozdzielenie prądów na obydwie strony równa była z obydwóch boków praca

${ }^{36}$ Por. J. Jundziłł, Transport i handel morski w późnym Cesarstwie Rzymskim w świetle „Listów” Euzebiusza Hieronima (IV w. n. e.), „Nautologia” 12 (1977) nr 2, 28-41.

${ }^{37} \mathrm{~W}$ Żywocie św. Porfiriusza autorstwa Marka Diakona (Vita S. Porfirii 33, thum. I. Milewski, Gdańsk 2003, 117) jest informacja, że biskup Jan z Cezarei uważał, iż już we wrześniu było za późno, by wybierać się w podróż morską.

${ }^{38}$ Por. R. Chevallier, Voyages et déplacements dans l'Empire Romain, Paris 1988, 119; A.L. Udovitch, Time, the sea and society: duration of commercial voyages on the southern shores of the Mediterranean during the high Middle Ages, Princeton 1981, 503-546; J. Jundziłł, Rzymianie a morze, Bydgoszcz 1999, 16.

${ }^{39}$ Hieronymus, Epistula 108, 6, ŹMT 61, 162.

${ }^{40}$ Hieronymus, Epistula 60, 7, ŹMT 55, 85: „Et sicut hi qui in brevi tabella terrarum situs pingunt”. Na temat nawigacji rzymskiej w okresie republiki zob. S. Ducin, Sztuka nawigacji w Rzymie w okresie Republiki, w: Morze w kulturze starożytnych Greków i Rzymian, red. A. Rostropowicz, Opole 1995, 221-236.

${ }^{41}$ Łac. Carina, por. Hieronymus, Epistula 60, 19, ŹMT 55, 94.

${ }^{42}$ Łac. Clavus i gubernaculum, por. Hieronymus, Epistula 1, 2, ŹMT 54, 1; 100, 14, ŹMT 61, 108.

${ }^{43}$ Por. Hieronymus, Epistula 14, 6, ŹMT 54, 32; 1, 2, ŹMT 54, 1.

${ }^{44}$ Por. Hieronymus, Epistula 108, 6, ŹMT 61, 162.

${ }^{45}$ Por. Hieronymus, Epistula 14, 10, ŹMT 54, 35.

${ }^{46}$ Por. Hieronymus, Epistula 53, 11, ŹMT 55, 35.

${ }^{47}$ Por. Hieronymus, Epistula 1, 2; 15, 2, ŹMT 54, 1, 38. 
i to, czego nie można było wytrzymać równocześnie, dało się znieść dzięki temu podziałowi"48.

Oczywiście w tamtym okresie nie było mowy o oddzielnych pomieszczeniach dla podróżujących statkiem. Jedynie ludzie bardzo majętni mogli korzystać z „kabin oficerskich”49. Na statkach handlowych całe miejsce pod pokładem zajmował ładunek, podróżni zaś zwykle przebywali pod gołym niebem, a przed deszczem czy upałem chroniły ich porozwieszane płachty na kształt namiotów. Każdy sam przygotowywał sobie posiłek. Niedogodnością była niemożliwość odizolowania się od przypadkowych towarzyszy, przykra szczególnie dla mnichów i kobiet ${ }^{50}$.

Z obfitej korespondencji dostarczanej Hieronimowi widać też, że często wśród podróżujących statkami byli duchowni, przez których owe listy były przekazywane $^{51}$. W jednym przypadku list dostarcza Hieronimowi osoba świecka, o czym świadczy następujący tekst:

„Właściciel okrętu Zenon, przez którego - jak mówisz - posłany był do mnie list Twej Świątobliwości, oddał mi jeden tylko krótki list”52.

Istniała także możliwość wynajęcia statku na określoną podróż, jak ponoć uczynił pewien młody diakon, z zamiarem porwania z klasztoru dziewicy poświęconej Bogu ${ }^{53}$. Lecz czy rzeczywiście wynają on cały statek, czy jedynie miejsce na nim, pozostaje pytaniem bez odpowiedzi. Juliusz Jundziłł zauważa, że czasem mnisi byli jedynymi pasażerami na statkach, co świadczyłoby o tym, że owe jednostki pływające były własnością klasztorów ${ }^{54}$. Przytaczana przez niego reguła Pachomiusza nie mówi o tym jasno, aczkolwiek o podróżach mnichów wspomina i wprost zakazuje im podróżowania z kobietami.

Bez względu na pogodę, podróże morskie, w powszechnej opinii, były niebezpieczne. Świadczą o tym m.in. słowa Hieronima skierowane do mnicha Rufina: „morze zawsze niepewne dla żeglujących”55. W kilku miejscach wymienia on niebezpieczeństwa, na jakie narażone były statki:

„Wiele przypadków spotyka żeglujących. Jeśli silniej wieje wiatr, może skończyć się burzą. Jeśli pogoda łagodniej ledwo powierzchnię wody porusza, grozi napad piratów. Tak więc się dzieje, że powierzeni łupince statku albo

\footnotetext{
${ }^{48}$ Hieronymus, Epistula 100, 14, ŹMT 61, 108.

${ }^{49}$ Por. L. Casson, Podróże w starożytnym świecie, thum. A. Flasińska - M. Radlińska, Wrocław - Warszawa 1981, 312.

${ }^{50}$ Por. Iwaszkiewicz, Wstęp, OŻ 13, 40.

${ }^{51}$ Hieronim bał się, że właściciel statku, z pochodzenia będący Grekiem, mógł zgubić powierzony mu łaciński list, por. Hieronymus, Epistula 72, 1, ŹMT 55, 175.

${ }^{52}$ Hieronymus, Epistula 72, 1, ŹMT 55, 175.

${ }^{53}$ Por. Hieronymus, Epistula 147, 6, ŹMT 68, Kraków 2013, 89.

${ }^{54}$ Por. Jundziłł, Rzymianie a morze, s. 101.

${ }^{55}$ Hieronymus, Epistula 3, 2, ŹMT 54, 8.
} 
obawiają się niebezpieczeństwa, albo je przeżywają, a jedno nie jest gorsze od drugiego: albo ciagle bać się śmierci, albo doświadczyć tego, czego się boi" ${ }^{56}$.

Oprócz burz, trwogę podróżujących wzbudzały także wiatry, skały, rafy podwodne i wielkie fale ${ }^{57}$. Nawet jeden z posłańców, który miał dostarczyć korespondencję Hieronimowi, do takiego stopnia ,zląkł się niebezpieczeństw morza i wyrzekł się zamiaru żeglugi" ${ }^{58}$. Groźne oblicze morza zostało także podkreślone w liście z 397 r., w którym Hieronim dziękuje Kastrucjuszowi:

„Przybyłeś aż do Cissy ${ }^{59}$ i nie lękałeś się fal Morza Adriatyckiego ani niebezpieczeństw Morza Egejskiego, chociaż dzięki swemu pochodzeniu z Panonii jesteś raczej «zwierzęciem lądowym»"

W tym miejscu należy także zwrócić uwagę na to, w jaki sposób geografia Hieronima ma się do współczesnej, jeśli nie jest to przypadkowe przesunięcie kolejności podczas wymieniania nazw mórz. Znaczyłoby to bowiem, że dla Hieronima Adriatyk sięgał dalej na południe, obejmując Morze Jońskie, zaś ono leżałoby na wschód od Morza Egejskiego. Poza tym z innego listu ${ }^{61}$ wynika, że Hieronim nazywa Adriatykiem obecne Morze Jońskie. Oczywiście, nazwę Adriatyk stosowano także na określenie basenu Morza Jońskiego, którego nazwa wskutek tego nie była używana. Jednak u Hieronima nazwa Morze Jońskie występuje ${ }^{62}$. Od Hieronima dowiadujemy się także, że z Indii, Persji i Etiopii przyjmowane były codziennie w Ziemi Świętej thumy mnichów ${ }^{63}$. Aby dostać się do Palestyny z Indii, należało pokonać Ocean Indyjski i Morze Czerwone, po którym żegluga była utrudniona $\mathrm{z}$ powodu raf koralowych i mielizn ${ }^{64}$. Pamiętać jednak należy, że w potocznej mowie starożytnych Indie to kraina leżąca za Persją, czyli niekoniecznie tylko Półwysep Indyjski. Oprócz niesprzyjających warunków naturalnych, podróż morska nie była także wolna od piratów, wśród których na Morzu Egejskim przodowali rozbójnicy goccy ${ }^{65}$.

${ }^{56}$ Hieronymus, In Isaiam XIII. Prol., PL 24, 441-442: „Multi casus opprimunt navigantes. Si vehementior flaverit ventus, tempestas formidini est. Si aura moderatior summa jacentis elementi terga crispaverit, piratarum insidias pertimescunt. Atque ita fit, ut fragili animae ligno creditae, aut metuant periculum, aut sustineant: quorum utrumque altero gravius est, vel mortem timere perpetuo, vel quam timueris sustinere".

${ }^{57}$ Por. Hieronymus, Epistula 77, 8, ŹMT 55, 201; 3, 4, ŹMT 54, 9; 45, 1, ŹMT 54, 183; 43, 3, ŹMT 54, 181; 95, 1, ŹMT 61, 54.

${ }^{58}$ Hieronymus, Epistula 105, 1, ŹMT 61, 120.

${ }^{59}$ Cissa - miejscowość nad Adriatykiem w północnej Dalmacji.

${ }^{60}$ Hieronymus, Epistula 68, 1, ŹMT 55, 149.

${ }^{61}$ Por. Hieronymus, Epistula 108, 7, ŹMT 61, 163.

${ }^{62} \mathrm{Na}$ temat geografii Hieronima por. S. Weingarten, Jerome's geography, StPatr 43 (2006) 537-541.

${ }^{63}$ Por. Hieronymus, Epistula 107, 2, ŹMT 61, 150.

${ }^{64}$ Por. Hieronymus, Epistula 125, 3, ŹMT 63, 154.

${ }^{65}$ Por. Iwaszkiewicz, Wstęp, OŻ 13, 41. 
4. Podróż Pauli. Wróćmy do podróży do Ziemi Świętej. Kilka miesięcy po opuszczeniu Rzymu przez Hieronima, w podróż wyruszyły Paula i Eustochium, w towarzystwie innych kobiet ze swojego otoczenia. One także zdecydowały się na drogę morską. Statek wypłynąwszy z Portus Romanus zatrzymał się na wyspie Pontiae ${ }^{66}$ położonej w Zatoce Gaetańskiej. Wyspa ta znana była $\mathrm{z}$ tego, że cesarz Domicjan, za przywiązanie do wiary, zesłał na nią swoją kuzynkę - Flawię Domicyllę ${ }^{67}$. Biorąc pod uwagę powody śmierci wspomnianej kobiety, Paula i Eustochium z wielką ciekawością oglądały celę jej męczeństwa. Częstą praktyką było bowiem, że żeglarze, widząc zainteresowanie i ciekawość podróżnych miejscami które mijali, płynęli wolniej, by ludzie ci mogli podziwiać mijane otoczenie ${ }^{68}$.

Kobiety następnie przepłynęły między, słynnymi z Odysei Homera, Scyllą i Charybdą i dotarly nad Adriatyk. Kolejny odcinek podróży wyznaczony był nieco inaczej niż u Hieronima, ponieważ zatrzymały się w Metonie ${ }^{69}$, na południowo-zachodnim Peloponezie, a stamtąd przez Maleę i Cytherę ${ }^{70}$ dotarły na Cypr, zatrzymując się również u biskupa Epifaniusza. Z Salaminy dostały się do Seleucji, gdzie odwiedziły znajomego Paulina, i stąd, jak z podziwem pisze Hieronim:

„W połowie zimy pełna żarliwej wiary dostojna kobieta, którą dawniej eunuchowie nosili na rękach, ruszyła w drogę do Antiochii siedząc na ośle"71.

Pisma Hieronima nie informują nas dokładnie, jaką szybkość osiągały statki na przełomie IV/V wieku. Jedynie podana przez niego długość rejsu przez Morze Czerwone pozwala obliczyć, że statek ów płynął ze średnią prędkością 1,25 węzła. Wynik ten jest jednakże wattpliwy, ze względu na to, jak Hieronim rozumie akwen Morza Czerwonego. Literatura przedmiotu podaje prędkości ówczesnych statków handlowych od 0,5 do 6 węzłów: w ten sposób Melania Starsza z Cezarei do Rzymu płynęła statkiem 20 dni $^{72}$. Z Ostii do Aleksandrii podróż trwała $10 \mathrm{dni}^{73}$, z Aleksandrii do Marsylii $30 \mathrm{dni}^{74}$. Pod tym względem droga morska była więc o wiele bardziej korzystna niż lądowa. W Itinerarium

${ }^{66}$ Obecnie Ponza.

${ }^{67}$ Por. Cassius Dio, Historia Romana LXVII 14, thum. M. Kaźmierska - D. Latanowicz-Domecka: Kasjusz Dion, Księgi Flawijskie (Historia rzymska LXV-LXVII), Poznań 2011, 104-105; Eusebius, HE III 18, tłum. A. Lisiecki, POK 3, Kraków 1993, 113; Hieronymus, Epistula 108, 7, ŹMT 61, 163.

${ }^{68}$ Por. Gorce, Les voyages, s. 109.

${ }^{69}$ Był to niewielki port, do którego przypływały statki płynące między cieśniną Mesyńską a Grecją.

${ }^{70}$ Przylądek Malea znajduje się na południowo-wschodnim Peloponezie. Do wyspy Cythery (obecnie Cerigo) odległość wynosiła $8 \mathrm{~km}$.

${ }^{71}$ Hieronymus, Epistula 108, 7, ŹMT 61, 164.

${ }^{72}$ Por. Gorce, Les voyages, s. 110.

${ }^{73}$ Por. Iwaszkiewicz, Wstęp, OŻ 13, 39.

${ }^{74}$ Por. Gorce, Les voyages, s. 111. 
Burdigalense znajdujemy informację, że dziennie pieszo pokonywano 20 mil rzymskich ${ }^{75}$, czyli tyle samo, co wozy pocztowe zaprzężone w woły. W ten sposób jedni i drudzy korzystali z tych samych zajazdów pocztowych. Melania Młodsza, której podróż z Konstantynopola do Jerozolimy zajęła 44 dni, przemierzała dziennie średnio $26 \mathrm{mil}^{76}$.

5. Podróż wspólna. Po pierwszym etapie oddzielnego podróżowania, Paula spotkała się z Hieronimem i wszyscy wspólnie udali się w kierunku Jerozolimy. Miało to miejsce w Antiochii bądź jeszcze w Salaminie. Hieronim w 108. liście do Eustochium bardzo szczegółowy sposób opisuje miejsca, które Paula zwiedzała:

„Kiedy opuściła kolonię rzymską Beryt ${ }^{77}$ i starożytne miasto Sydon ${ }^{78}$, wstapiła na wybrzeżu w Sarepcie do wieżyczki Eliasza, stąd po uczczeniu Zbawiciela Pana przybyła po piaskach Tyru, na których Paweł padł na kolana (Dz 21, 3-5), do Akkonu ${ }^{79}$, zwanego teraz Ptolomaidą i przez pola Mageddo ${ }^{80}$, które były świadkiem zabójstwa Jozjasza, weszła do ziemi Filistynów. Obejrzała z podziwem ruiny Dor $^{81}$, miasta dawniej bardzo potężnego, zaś wracając zwiedziła wieżę Stratona, którą Herod król judzki nazwał Cezareą ${ }^{82}$, ku czci cesarza Augusta. Tam widziała dom Korneliusza, niczym kościół Chrystusa, i skromny domek Filipa oraz mieszkanie czterech dziewic prorokiń. Następnie zwiedziła Antipatris ${ }^{83}$, miasteczko na wpół zburzone, które Herod nazwał tak od imienia swego ojca, Lyddę przemianowaną na Diospolis ${ }^{84}$, wsławioną uzdrowieniem Eneasza i wskrzeszeniem Dorkady. Niedaleko stąd oglądała Arymateję, wioskę Józefa, który pana pochował, i Nobe, miasto dawniej kapłańskie, teraz grobowce pozabijanych. Widziała także Joppe ${ }^{85}$, port, z które-

${ }^{75}$ Łac. mille passus, równoważność 1000 kroków - podwójnych, czyli 1478,5 metrów, por. P. Iwaszkiewicz, Pielgrzym z Burdigali, „Meander” 46 (1991) 63-75; Itinerarium Burdigalense, ed. P. Geyer, CCL 175, 1-26.

${ }^{76}$ Casson, Podróże w starożytnym świecie, s. 226.

${ }^{77}$ Beryt (obecnie Bejrut) w czasie walk o tron Seleucydów został zniszczony, zaś jego odbudowy podjęli się Rzymianie zmieniając mu nazwę na Colonia Iulia Augusta Felix Berytus. Miasto słynęło ze znakomitej szkoły prawniczej, rozbudowanej i odnowionej przez Teodozjusza II w 425 roku.

${ }^{78}$ Sydon był portowym miastem, jednym z najważniejszych w Fenicji.

${ }^{79}$ Akkon (obecnie Akka) był najsłynniejszym portem w Palestynie.

${ }^{80}$ Megiddo - jego początki datuje się na IV tys. prz. Chr. Król Salomon podjął się odbudowy jego warowni i spichlerzy. Obecnie miasto wpisane jest na listę światowego dziedzictwa kultury UNESCO.

${ }^{81}$ Miasto Dor zostało zburzone w IV wieku po Chr.

${ }^{82}$ Chodzi o Cezareę Palestyńską, por. Plinius, Historia Naturalis V 69.

${ }^{83}$ Chodzi o miejscowość Afek.

${ }^{84}$ Obecnie miasto Lod położone w Dystrykcie Centralnym w Izraelu. Znane od czasów starożytnych jako Diospolis, a następnie Lidda (Lydda). Zniszczone przez Cestiusza Gallusa, a następnie przez legion Wespazjana.

${ }^{85}$ Jaffa od czasów króla Salomona była jednym z ważniejszych portów Jerozolimy. 
go uciekł Jonasz i - niech mi wolno będzie czerpać z baśni poetów - który był świadkiem przywiązania Andromedy do skały. W powrotnej drodze odwiedziła Nikopolis, przedtem zwane Emaus ${ }^{86}$, gdzie Pan, poznany przy łamaniu chleba, poświęcił dom Kleofasa na kościół. Wyruszając stąd wstąpiła do niższego i wyższego Bethoron, miasta założonego przez Salomona, a potem zniszczonego przez różne burze wojenne. Po prawej stronie ujrzała Ajalon i Gabaon, gdzie Jozue, syn Nuna, walczył z pięcioma królami i rozkazywał słońcu i księżycowi, a Gabaonitów za podstępne wyłudzenie sojuszu skazał na dostarczanie wody i drzewa. W mieście Gabaa, zburzonym doszczętnie, zatrzymała się na krótko, wspominając grzech mieszkańców i nałożnicę poćwiartowaną na kawałki oraz trzystu mężów z pokolenia Beniamina zachowanych ze względu na Apostoła Pawła"87.

Do Jerozolimy, której kilka alternatywnych nazw wymienia Hieronim Jebus, Salem ${ }^{88}$, Jeruzalem - dotarli od strony północnej, gdzie znajdowało się mauzoleum królowej Heleny z Adiabene ${ }^{89}$. Tu rozpoczął się kolejny etap ich podróży, którego celem był dokładny objazd południowej Judei, pustyni Negew i Hebronu. W miejscach, które zwiedzali, zobaczyli m.in. grób Zmartwychwstania, gdzie z czcią ucałowała płytę grobową ${ }^{90}$, potem z uszanowaniem obejrzała filar, ,podtrzymujący portyk kościoła, zbroczony krwią Pana, do którego, jak mówią, przywiązano Pana i ubiczowano" "1. Odwiedziła też stajenkę, w której narodził się Jezus ${ }^{92}$, komórkę Sary wraz z kołyską Izaaka ${ }^{93}$. Ten sam etap podróży relacjonuje Hieronim w Apologii przeciw Rufinowi:

„[...] w środku zimy i w najostrzejszym mrozie wkroczyłem do Jerozolimy. Widziałem wiele cudów i naocznie potwierdziłem to, co przedtem wieść przyniosła. Stamtąd udałem się do Egiptu, zwiedziłem klasztory Nitrii i zobaczyłem między chórami świętych ukrywające się węże. Stąd pośpiesznie powróciłem do mojego drogiego Betlejemu, gdzie adorowałem żłóbek i kołyskę Zbawiciela. Widziałem również to przesławne jezioro, ale nie oddałem się bezczynnemu odpoczynkowi, natomiast wiele się nauczyłem czego dotąd nie wiedziałem" $"$.

Wielkie wzruszenie wywołała w nich panorama zniszczonych Sodomy i Gomory ${ }^{95}$. Następnie rozpoczęli zwiedzanie okolic Jerozolimy - Betanii, gdzie

\footnotetext{
${ }^{86}$ Emaus zostało rozbudowane przez Juliusza Afrykańczyka i nazwane Nikopolis.

${ }^{87}$ Hieronymus, Epistula 108, 8, ŹMT 61, 164-165.

${ }^{88}$ Hieronymus, Epistula 73, 2, ŹMT 55, 180.

${ }^{89}$ Por. Epistula 108, 9, ŹMT 61, 165.

${ }^{90}$ Por. tamże.

${ }^{91}$ Tamże, ŹMT 61, 166.

${ }^{92}$ Por. tamże 10, ŹMT 61, 166.

${ }^{93}$ Por. tamże 11, ŹMT 61, 168.

${ }^{94}$ Hieronymus, Apologia adversus Rufinum III 22, SCh 303, 272, PSP 51, 120.

${ }^{95}$ Por. Hieronymus, Epistula 108, 11, ŹMT 61, 168.
} 
„Paula weszła do grobu Łazarza, zobaczyła gospodę Marii i Marty i Betfage" ${ }^{" 96}$. Kontynuując wędrówkę udali się do Jerycha, nad Jordan ${ }^{97}$ i stamtąd do Samarii i Galilei. Następnie obeszli Nazaret z domem Zwiastowania oraz grotę, w której żył Chrystus, Kanę i Kafarnaum, przepłynęli Jezioro Galilejskie i udali się na górę Tabor ${ }^{98}$. Hieronim kończy opis następująco:

„Prędzej dzień się skończy niż mój wywód, jeśli zechcę prześledzić wszystko, co z niewiarygodną wiarą przemierzyła czcigodna Paula" $"$.

Po zobaczeniu wszystkich ciekawych miejsc w Ziemi Świętej, Hieronim i Paula wraz z towarzyszami udali się pustynną drogą na południe - do Egip$\mathrm{tu}^{100}$; bardzo modnym w tamtym czasie była również wizyta w pustynnej kolebce monastycyzmu. Ówcześni podróżni, których celem była pielgrzymka, swoje podróże zaczynali bezpośrednio od Aleksandrii, by zakończyć je właśnie w Ziemi Świętej.

Nie ma pewności, jak długo Hieronim i Paula przebywali w Aleksandrii; w każdym razie wiosną bądź latem 386 r., drogą wodną dotarli do Nitrii, zamieszkiwanej przez ascetów ${ }^{101}$. Paula początkowo myślała nawet o dołączeniu do tamtejszej wspólnoty mnisiej, jednak Hieronimowi udało się ją odwieźć od tego planu. Mimo swoich wcześniejszych pomysłów, dotyczących wyboru Jerozolimy na docelowe miejsce działalności, postanowili swą przyszłość związać z Betlejem, gdzie w 386 r. osiedlili się na stałe ${ }^{102}$. Majętność Pauli pozwoliła jej na fundację klasztorów żeńskich oraz klasztoru męskiego. Hieronim wiele czasu przeznaczał na pracę związaną z działalnością hospicjum dla podróżnych ${ }^{103}$. W związku z tym, że było ono odwiedzane przez coraz większą liczbę podróżnych, dość szybko nastąpiła jego rozbudowa ${ }^{104}$. W Listach wiele razy spotykamy się z informacją dotyczącą zakładania miejsc wypoczynku dla podróżujących osób:

\footnotetext{
${ }^{96}$ Tamże 12, ŹMT 61, 169.

${ }^{97}$ Por. tamże, ŹMT 61, 169.

${ }^{98}$ Por. tamże 13, ŹMT 61, 171.

${ }^{99}$ Tamże, ŻMT 61, 171.

${ }^{100}$ Por. tamże 14, ŹMT 61, 171.

${ }^{101}$ Por. tamże, ŹMT 61, 171-172. O podróży do Nitry Rufina i Melanii zob. Historia monachorum in Aegypto 21, PL 21, 454.

${ }^{102}$ Od opuszczenia Rzymu Hieronim i Paula zamierzali osiedlić się w Jerozolimie, a nie w Betlejem. Można przypuszczać, że decyzja dotycząca zmiany ich docelowego miejsca zamieszkania, wynikała z tego, że Hieronim być może obawiał się przewagi Rufina, bardziej doświadczonego w kwestii kierownictwa wspólnotą monastyczną, analogicznie jak i Paula - Melanii, por. J. Steinmann, Saint Jérôme, Paris 1958, 171; H. Silvan, On the way to Bethlehem. Mary between Jerome and John of Jerusalem, w: The power religion in late antiquity, Farnham 2009, 369-381.

${ }^{103}$ Por. Hieronymus, Epistula 107, 2, ŹMT 61, 150.

${ }^{104}$ Por. Hieronymus, Epistula 66, 14, ŹMT 55, 143.
} 
„Nabywają hospicjum ${ }^{105}$ i staje się ono schronieniem dla tłumów. «Nie masz bowiem cierpienia w Jakubie ani boleści w Izraelu» (Lb 23, 21). Morza sprowadzają tych, których ziemia przyjmuje na swym łonie. Niech Rzym wyśle podróżnych, których zachęca do podróży możliwość schronienia na wybrzeżu. To, co Publiusz uczynił raz na wyspie Melicie ${ }^{106}$ dla jednego Apostoła i - nie chcę wywołać dysputy - na jednym tylko okręcie, oni czynią często dla wielu ludzi. Nie tylko udziela się wsparcia niezamożnym, ale hojność życzliwa dla wszystkich wspomaga również i tych, którzy coś posiadają. Cały świat dowiedział się prawie równocześnie o założeniu hospicjum ${ }^{107} \mathrm{~W}$ porcie rzymskim. Brytania dowiedziała się o tym w lecie, a Egipcjanie i Partowie już na wiosnę"108.

O tej samej gospodzie Hieronim wspomina także w liście do Pammachiusza ${ }^{109}$ pisząc: „Słyszę, że w porcie rzymskim założyłeś gospodę dla podróżnych"110. Podczas wykopalisk archeologicznych w Ostii, przyjęto pewną hipotezę, według której stwierdzono, że jeden z obiektów - duży budynek, w którym wokół wewnętrznego kolumnadowego dziedzińca znajdowały się pokoje - można identyfikować właśnie z fundacją Pammachiusza ${ }^{111}$. Oprócz ksenodochiów oraz klasztorów, które przeznaczone były wyłącznie dla osób wierzących, funkcjonowały także gospody należące do poczty państwowej oraz do osób prywatnych $^{112}$.

Na przełomie IV i V wieku ludzie podróżowali w miejsca bardzo różne, niekiedy egzotyczne nawet dla nas. Analogicznie, jak w czasach obecnych, tak i w tamtym czasie, dużą rolę odgrywali przewodnicy o bujnej wyobraźni, pokazując podróżnym ławkę z Nazaretu, na której siadywał jako uczeń Jezus, jego pierwszy zeszyt, czy też słup soli, w który została zamieniona żona Lota. Interesującym faktem było oglądanie kolumny podtrzymującej krzyż, na którym został stracony św. Piotr; ciekawostką jest, w jaki sposób owa kolumna istniała w Jerozolimie, skoro powinna znajdować się w Rzymie ${ }^{113}$ ! Podobne praktyki miały miejsce także w Egipcie, gdzie np. piramidy określano silosa-

${ }^{105}$ Mowa o hospicjum założonym przy Bramie Rzymskiej.

${ }^{106}$ Melita - wyspa na Adriatyku.

${ }^{107}$ Ksenodocheion było miejscem, w którym przyjmowano obcych. Początkowo taką fundację określano terminem basileias, por. Xenodocheion, RE IX A2 1489-1490; S. Longosz, Ksenodochium - hospicjum wczesnochrześcijańskie, VoxP 16 (1996) z. 30-31, 275-336 (tam też zebrana bibliografia); Pawłowska, Urbs sacra, s. 215-245.

${ }^{108}$ Hieronymus, Epistula 77, 10, ŹMT 55, 202-203.

${ }^{109}$ Pammachiusz był założycielem hospicjum - gospody przy Bramie Rzymskiej, gdzie zatrzymywali się podróżni i pielgrzymi.

${ }^{110}$ Hieronymus, Epistula 66, 11, ŹMT 55, 141.

${ }^{111}$ Por. R. Meiggs, Roman Ostia, Oxford 1960, 169, 403.

112 Por. Casson, Podróże w starożytnym świecie, s. 140-155.

${ }^{113}$ Por. tamże, s. 222. 
mi Józefa ${ }^{114}$. Podróżujący z wielką chęcią zaopatrywali się także w stosowne pamiątki. Kilkanaście kilometrów na północ od Rzymu, w klasztorze w Farfie, znajduje się kolekcja charakterystycznych souvenirów z Ziemi Świętej. W czasie ich odkrycia, były one dokładnie opisane i pozawijane w białą tkaninę. Wśród etykiet znajdują się m.in. następujące opisy: „Z Góry Kalwarii”, „Ze skały Góry Oliwnej”, „Z grobu naszego Pana”115. Najbardziej pożądaną pamiątką były krople oliwy z lampek płonących u grobów męczenników. Handlarze specjalnie w tym celu sprzedawali nawet małe flaszeczki, mniej lub bardziej wyrafinowane pod względem artystycznym, ze srebra bądź szkła, w zależności od majętności nabywcy.

Niech podsumowaniem powyższych rozważań, dotyczących niebezpieczeństw grożących podróżującym mnichom i duchownym przełomu IV i V wieku, będzie cytat, na który powołuje się także i Hieronim ze Strydonu:

„Dla kochających nie ma nic twardego, żaden trud nie jest uciążliwy dla tego kto chce. [...] Kiedy ciężkie wydaje ci się to, co znosisz, czytaj drugi list Pawła do Koryntian: «[...] W podróżach częstych, w niebezpieczeństwach na rzekach, w niebezpieczeństwach od rozbójników, w niebezpieczeństwach od własnego narodu, w niebezpieczeństwach od pogan, w niebezpieczeństwach w mieście, w niebezpieczeństwach na pustyni, w niebezpieczeństwach na morzu, w niebezpieczeństwach wśród fałszywych braci. W pracy i trudzie, w częstym niespaniu i w głodzie, i pragnieniu, w postach bardzo częstych, w zimnie i nagości» (2Kor 11, 23-27)”"116.

\section{THE TRAVELS OF MONKS AND CLERGYMEN IN THE LIGHT OF SAINT JEROME}

\section{(Summary)}

Saint Jerome, the author of the Latin translation of the Holy Bible and Eusebius's Onomasticon, contributed to a large extent to the popularisation and development of the tourist-pilgrimage movement at the turn of the 4th and 5th centuries.

The aim of the present article is to present, in the light of Jerome's works, how people travelled, among others, to the Holy Land; how the author of the Letters travelled himself as well as how his companions, monks and clergymen travelled. What is more, the text presents which way(s) the most popular sea and land routes ran and what types of dangers the then travellers were exposed to. The article also shows which locations were most popular and which souvenirs were desirable by pilgrims.

\footnotetext{
${ }^{114}$ Por. E. Pfister, Der Reliquienkult im Altertum, Giessen 1909, 351.

${ }^{115}$ Por. Casson, Podróże w starożytnym świecie, s. 225.

${ }^{116}$ Hieronymus, Epistula 22, 40, ŹMT 54, 111-112.
} 


\section{ANEKS}

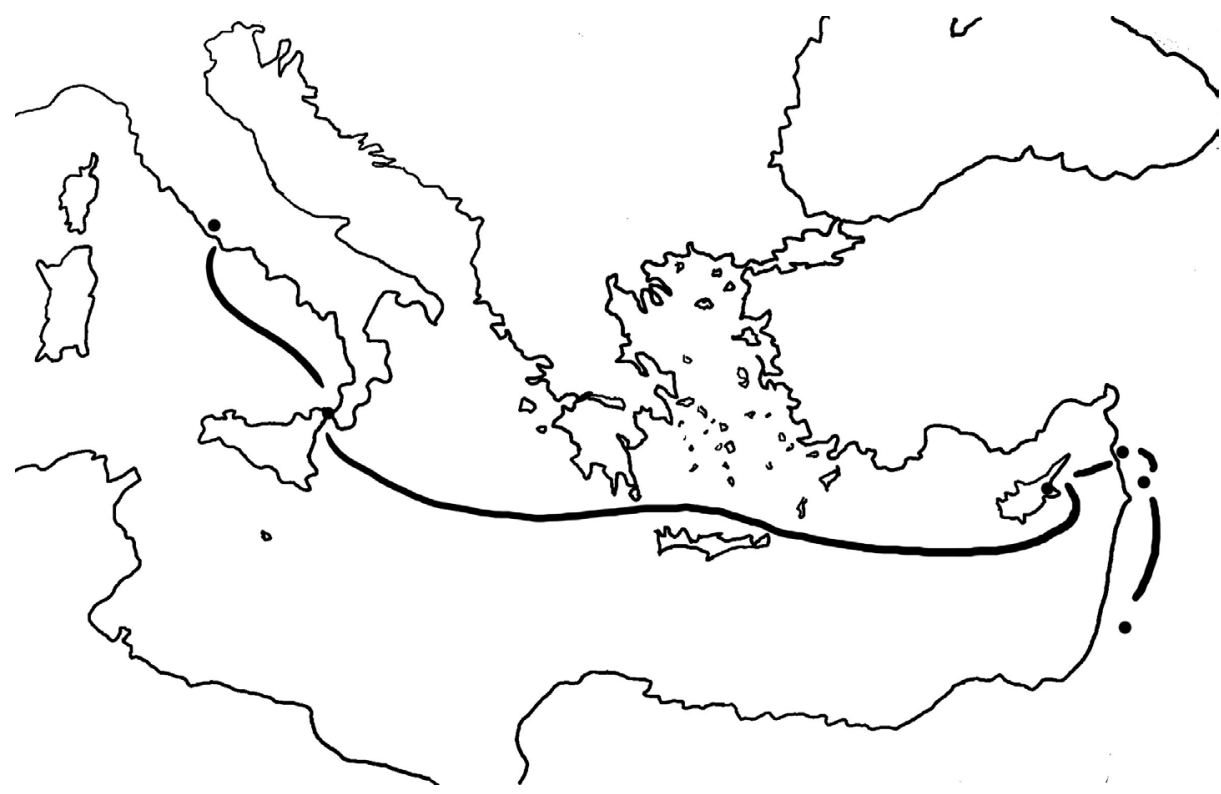

1. Podróż Hieronima, oprac. M. Ożóg

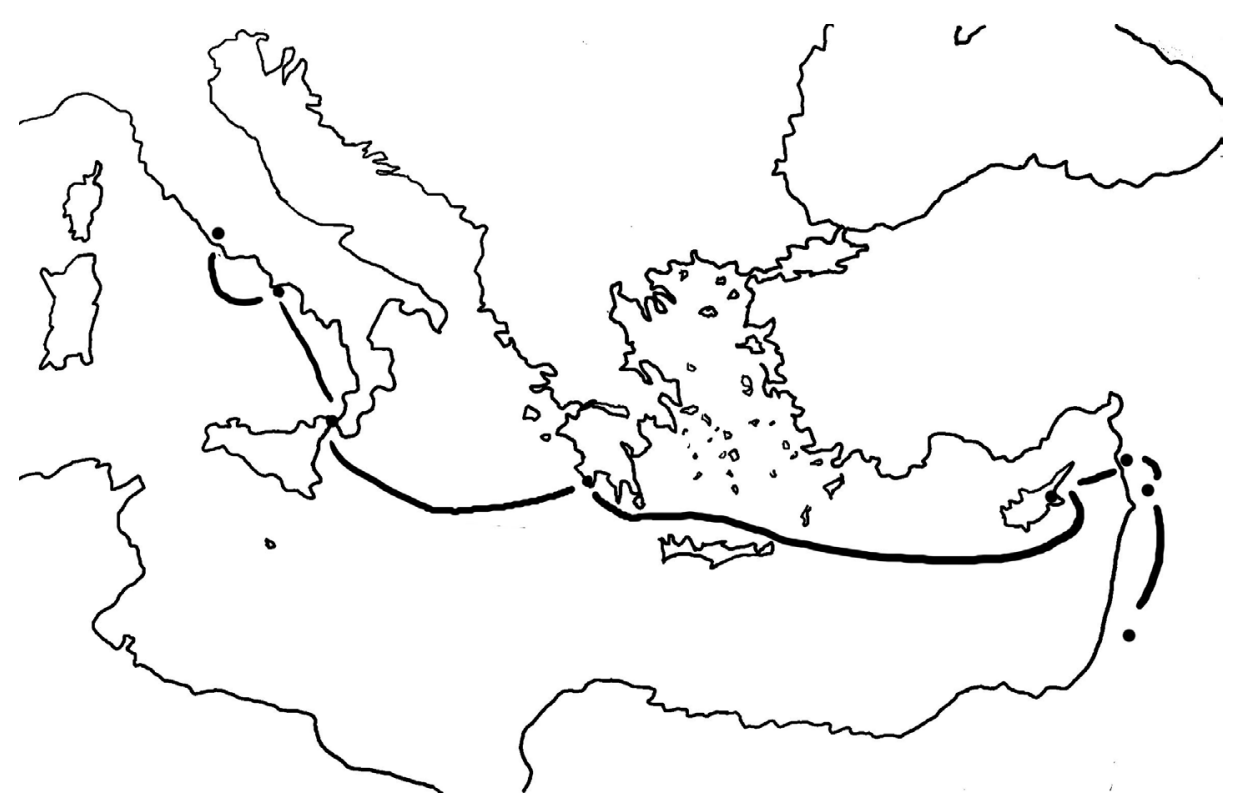

2. Podróż Pauli, oprac. M. Ożóg 